
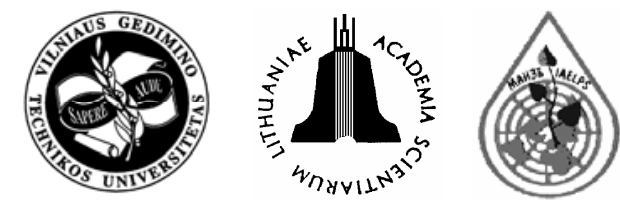

\title{
UTILIZATION OF SEWAGE SLUDGE FROM ACID CASEIN PRODUCTION FOR SOIL FERTILIZATION
}

\author{
Eglè Zuokaité ${ }^{1}$, Davidas Ščupakas ${ }^{2}$ \\ Dept of Environmental Protection, Vilnius Gediminas Technical University, \\ Saulètekio al. 11, LT-10223 Vilnius, Lithuania \\ E-mail: ${ }^{1} a a k @ a p . v g t u . l t ;{ }^{2}$ vasc16@takas.lt
}

Submitted 13 Mar 2007; accepted 8 May 2007

\begin{abstract}
Organic biodegradable waste composes a fair part of farm and vital activity waste. The disposal of this waste in municipal waste landfills pollutes the environment and soil. Therefore, the European Union and other countries look for alternatives to manage biodegraded waste. This paper seeks to analyse the properties of sludge that forms in the sewage treatment plants of the acid casein production, examines experience in managing and applying sludge. The results of an experiment show that sewage sludge from the acid casein production is suitable as a soil fertilizer for growing lettuce (Lactuca sativa L.) and garden cress (Lepidium sativum L.). After soil was fertilized with this sludge, the germination of lettuce and garden cress as well as the biomass of experimental alimentary plants increased. A suitable ratio of soil and sludge mixture was determined (for lettuce - 1:1, for garden cress - 3:1). Potassium sulphate which was added to a soilsludge mixture improved the values of fertility parameters of alimentary plants.
\end{abstract}

Keywords: acid casein, sewage sludge, fertilization.

\section{Introduction}

One of the urgent environmental problems in Lithuania is the treatment of organic biodegradable waste. The improperly treated organic waste causes danger to the environment and people's health due to gas (methane and carbon dioxide) discharged to ambient air, filtrate that pollutes the soil and ground water, and unpleasant smell $[1,2]$. Production waste from food industry companies is heavily contaminated with organic pollutants. Sewage amount and pollution of this waste depend on production branch, volume and technology applied. Acidity $\mathrm{pH}$ of sewage from milk processing to different food products ranges 5,5 to 7,6 BOD from 300 to 5000, and the amount of suspended substances from 250 to $1000 \mathrm{mg} / \mathrm{l}$, concentration value of phosphorus -20 to $60 \mathrm{mg} / \mathrm{l}$, nitrogen - 10 to $80 \mathrm{mg} / \mathrm{l}$. Especially high concentrations of $\mathrm{Ca}$ and $\mathrm{K}$ ions are found in the sewage of alcohol and sugar production companies [3, 4, 5].

Raw milk processing to food products, including casein, is one of the main food industry branches in Lithuania. Casein is an insoluble, leached out and dried substance, the main protein found in milk, obtained from skim milk by treating it with acid or after milk acidified due to activity of microorganisms that produce rennet. Casein is used for cheese or glue production depending on its properties.

Milk processing forms waste that is several times more contaminated with organic and biogenic substances compared to municipal waste. In the process of acid casein production sewage - whey, waste liquids of washed casein granules, waste water from technologic equipment and pipelines - is formed. Whey is a liquid milk residue which forms after fat and proteins are removed from milk. Sewage from washed casein granules is milk and chloride residues. A reaction of casein production waste is acid while neutral of other milk processing products.

Milk processing companies in Lithuania produce heavily contaminated waste, and liquid waste that go to treatment plants is used as fertilizers of the soil or kept in storage and treatment reservoirs [6]. Active acidification fermentation processes in the sewage from milk processing companies often disturb activity of biologic sewage treatment plants. Thus, local sewage treatment plants are built in milk processing companies. A scheme of a local sewage treatment technology in milk industry companies also includes a possibility to divide the biodestruction process into separate controlled stages. In this case biodestruction processes are accelerated, and the load of sewage treatment plants is reduced compared to the traditional sewage treatment technologies [7].

Large milk processing companies in western countries and Lithuania apply the following biologic sewage treatment technologies: systems with low-pressure air tanks and aeration systems with circulating oxidation canals [5]. The existing practice in Lithuania shows that the primary treatment of sewage from concentrated milk processing is available both in aerobic reactors (air tanks) and anaerobic reactors where consecutive processes take place, i e propionic acid fermentation of milk butter, acetogenesis and methanisation (obtaining methane $\mathrm{CH}_{4}$ gas). In modern plants activity of microorganisms is acti- 
vated by mechanisms of pressure, vibration, turbulence and air-liquid stage that have different levels of velocity [7]. Casein production waste is very effectively treated by using membranes and methods of ultrafiltration and reverse osmosis filtration, then waste meets the quality requirements of drinking water [8].

Waste from acid casein production company "Žalmargès pienas" is polluted with organic substances, mostly lactose. $\mathrm{BOD}_{7}$ of sewage is 25 000-35000 mg $\mathrm{O}_{2} / 1, \mathrm{pH}$ is less than 4,5 . Concentrated sewage contains very little fat and proteins. Sewage is treated in biologic treatment plants in several stages. The first stage includes a reduction of sewage acidity to $\mathrm{pH}>6$. Sewage is limed or affected with sodium hydroxide solution. Then sewage is aerated and treated using a mesophile mixture of bacteria. After the primary treatment sewage goes to an accumulator of the second treatment stage where $\mathrm{BOD}_{7}$ value of sewage is decreased to $<25$. The final sewage treatment takes place in a fish breeding reservoir. Sewage is treated until $\mathrm{BOD}_{7}$ reaches a value of less than 15 . A $3-$ $6 \mathrm{~cm}$ layer of sludge forms in the accumulator during the sewage treatment process. Then sludge is moved to a sludge accumulator.

Sludge from sewage treatment plants is utilized in various ways, including composting, fertilizer production, lawn growing, fuel briquette production, burning, earthworm breeding, biohumus production, etc. The cheapest way of sludge utilization is estimated to be the soil fertilization. If the price of this application way of sludge is 1 , then sludge accumulation costs 2 , while burning costs 4 times more. Almost every country, including France, Canada, England, Japan, Finland, Poland, Bulgaria and other ones, use sewage sludge for fertilization and composting $[9,10]$.

Depleted peat-bogs, quarries of clay, gravel and sand, landfills fall out of the metabolism cycle of biosphere after the live soil layer is removed. Sewage sludge is applied in recultivation of lands which are enriched with organic matter [10].

Due to an imbalance of nutritious matter sewage sludge is not always suitable for the soil fertilization without appropriate preparation. Sludge for fertilization can be prepared by mixing it with peat, sludge from lakes, ponds and streams, also straw, silage production waste, grain tailings, grass, leaves, sawdust, chopped branches, etc. During the mixing process sludge composition is enriched with components and nutritious matter are balanced. The main composting factors include aeration, humidity, acidity and duration of compost maturation. The quality of compost is influenced by particle structure and size, the amount of nitrogen, carbon, phosphorus and potassium. It was established that during compost production it is necessary to select the composted matter so that the ratio of carbon and nitrogen is $15: 1$ to $30: 1[7,9]$.

Sludge used as a fertilizer enriches the soil with nutritious matter and microelements, intensifies humification processes in the soil. Fields of intensive agriculture experience a 5-12 t/ha loss of organic matter every year. Sludge improves the soil structure, its physical properties, porosity, prevents formation of crust. Although agrochemical properties of sewage sludge are similar to those of muck, its application in the soil fertilization is restricted due to microbial and chemical pollution (contamination with heavy metals). Every country allows different marginal amounts of heavy metals in the sludge used for the soil fertilization. Following the European Union requirements and basing on data provided by the Institute of Ecology of Vilnius University, the Institute of Botany, the Institute of Agriculture, Water Management Institute and Lithuanian Geological Survey under the Ministry of Environment, a normative document LAND 20-2005 Requirements of Sewage Sludge Application in Fertilization and Recultivation was prepared [11, 12, 13].

The amount of heavy metals in the sludge in the sewage treatment plants of the acid casein production company "Žalmargès pienas" is low, meets the requirements of LAND 20-2005 and is classified as category I. According to microbiological-parasitological parameters, the sludge belongs to class A. Thus, this sewage sludge may be used for fertilization without any restrictions. There is a sufficient amount of soluble nitrogen and magnesium in sludge, but not enough of potassium and calcium and an excess of phosphorus. An imbalance of nutritious matter in sludge may be compensated by fertilizing the soil with potassium sulphate or potassium chloride. Farmland territories in our country with low and very low amounts of phosphorus form $61,8 \%$, while territories of low and very low amounts of lime form a significantly lower percentage $(43,0 \%)$. Therefore, phosphoric fertilizer is stated to better increase productivity of plants grown in the Lithuanian lands compared to potassium fertilizer [13].

The objectives of this investigation are the following:

1. To estimate the suitability of the sewage sludge from the acid casein production for the soil fertilization for growing lettuce and garden cress.

2. To carry out comparative analyses of experimental alimentary plants growing in substrates of different compositions.

3. To investigate the influence of potassium sulphate $\left(\mathrm{K}_{2} \mathrm{SO}_{4}\right)$ added to the substrate on the germination of garden cress and the increase of biomass.

\section{Investigation methods}

Methodology is applied in analysing the suitability of the sewage sludge from the acid casein production for fertilization of alimentary plants.

Sewage sludge from the acid casein production is characterized by big amounts of nitrogen and phosphorus but low amounts of potassium. As a fertilizer sludge should improve the productivity of cultivated plants. Lettuce and garden cress are planted in soil, standard peat substrate, sewage sludge, soil fertilised with sludge and soil fertilized with sludge and potassium sulphate. This investigation aims to prove the suitability of the sewage sludge from the acid casein production for the soil fertilization. 
Sewage sludge, soil without any fertilizers, universal peat substrate "Suli Flor", potassium sulphate, water, vegetative pots, and lettuce(Lactuca sativa L.) and garden cress (Lepidium sativum L.) seeds are used for this investigation.

Estimation of seed germination. The germination of seeds (lettuce and garden cress) is estimated in the beginning of the study. An analysis of germination is carried out with clean seeds of lettuce and garden cress. Paper towel is used as a medium for germination.

100 seeds are randomly selected from mixed clean seeds. The seeds are germinated on a plate covered with 4 layers of paper towel. The seeds are evenly put on the moist medium (paper towel) with even spaces among them in order the neighbouring seeds would not influence the growth of sprouts. The medium for germination is sufficiently moistened in the beginning of the study. Evaporation is reduced by putting the plates into plastic bags. The seeds are germinated in an indirect light at a temperature of $23{ }^{\circ} \mathrm{C}$. The duration of the study is 7 days. Sprouts are counted on the last day of the study.

Lettuce seeds are germinated in vegetative pots, i e plastic pots with a holey bottom used for a natural water leakage and to avoid an excess of water. An area of the vegetative pots is $0,023 \mathrm{~m}^{2}$.

Vegetative pots are filled with:

- peat substrate;

- soil;

- soil and sewage sludge 3:1;

- soil and sewage sludge 1:1;

- soil and sewage sludge 3:1 and potassium sulphate $\left(\mathrm{K}_{2} \mathrm{SO}_{4}\right)$;

- soil and sewage sludge 1:1 and potassium sulphate $\left(\mathrm{K}_{2} \mathrm{SO}_{4}\right)$;

- sewage sludge.

Experiments are carried out twice in order to avoid coincidences. 14 vegetative pots are analysed each having 25 seeds randomly chosen from mixed clean seeds. The seeds are evenly put into soil with even spaces among them so as the neighbouring seeds would not influence the growth of sprouts.

The number of germinated seeds is defined in each pot, an average value is expressed in percentage rounded down to the nearest whole number. The study lasts 28 days. The terraneous part of lettuce is weighed, the common biomass of each sample and an average mass of plants in a sample is calculated, and the height of lettuce is measured with a ruler on the final day of the study.

Vegetative pots with peat substrate; soil; soil and sewage sludge 3:1; soil and sewage sludge 1:1; sewage sludge are prepared for growing of garden cress.

Garden cress is grown in vegetative pots, i e plastic plates the area of which is $0,024 \mathrm{~m}^{2} .5$ vegetative pots with 100 seeds (randomly selected from mixed clean seeds) in each are analysed. The seeds are evenly put into soil with even spaces among them so that the neighbouring seeds would not influence the growth of the sprouts. The study is carried out without repetitions.

It is observed when the first sprouts of the garden cress appear in vegetative pots counting from the date of the experiment. The number of germinated seeds is determined in each pot and an average value is expressed in percentage. The study lasts 7 days. Differences in vegetation parameters of garden cress in experimental and check pots are recorded in photographs.

Lettuce and garden cress are grown at a temperature of $17-23{ }^{\circ} \mathrm{C}$. The room where the experiment is carried out is located in the north-western part of a building. Direct sunlight reaches the room only in the evening during the sunset. The samples are put on a windowsill and periodically turned $180^{\circ}$ in order all the plants get enough sunlight. Plants are watered according to the needs, air temperature and a visual humidity of soil: $100 \mathrm{ml}$ for each pot of lettuce every 5 days, $50 \mathrm{ml}$ for each pot of garden cress every second day. All the samples are grown under equal conditions: the same temperature and lighting, watered with the same amount of water and at the same time.

\section{Investigation results}

Estimation of seed germination. The estimated germination of lettuce and garden cress was $96 \%$ and $95 \%$, respectively. It was found out that the seeds were fertile and suitable for the experiment.

Analyses carried out during the growing of lettuce. The germination of seeds was estimated after 7 days of preparation of vegetative pots. The lowest germination level of lettuce was noticed in the check sample of soil only $88 \%$. The highest germination level was found in the substrate of soil and sewage sludge $-96 \%$ (Table 1).

Table 1. Seed germination data from substrates of different composition

\begin{tabular}{|c|c|c|c|}
\hline \multirow{2}{*}{$\begin{array}{l}\text { Substrates of different } \\
\text { composition }\end{array}$} & \multirow{2}{*}{$\begin{array}{l}\text { Seed germi- } \\
\text { nation, } \%\end{array}$} & \multicolumn{2}{|c|}{$\begin{array}{c}\text { Differences compared } \\
\text { to check samples, } \%\end{array}$} \\
\hline & & $\begin{array}{c}\text { Peat } \\
\text { substrate }\end{array}$ & Soil \\
\hline Peat substrate & 94 & - & +6 \\
\hline Soil & 88 & -6 & - \\
\hline $\begin{array}{l}\text { Soil and sewage } \\
\text { sludge } 3: 1\end{array}$ & 94 & 0 & +6 \\
\hline $\begin{array}{l}\text { Soil and sewage } \\
\text { sludge } 3: 1 \text { and } 1,0 \mathrm{~g} \\
\mathrm{~K}_{2} \mathrm{SO}_{4}\end{array}$ & 92 & -2 & +4 \\
\hline $\begin{array}{l}\text { Soil and sewage } \\
\text { sludge } 1: 1\end{array}$ & 96 & +2 & +8 \\
\hline $\begin{array}{l}\text { Soil and sewage } \\
\text { sludge } 1: 1 \text { and } 1,0 \mathrm{~g} \\
\mathrm{~K}_{2} \mathrm{SO}_{4}\end{array}$ & 84 & -10 & -4 \\
\hline Sewage sludge & 92 & -2 & +4 \\
\hline
\end{tabular}

Photographs of the samples with plants were taken on the $10^{\text {th }}$ day of the study. It was noticed that lettuce grew poorly without any fertilizers, whereas it grew taller and its leaves were bigger when it was fertilized with sludge. The differences between the fertilized and the unfertilized lettuce increased with further growth of lettuce (Fig 1). 


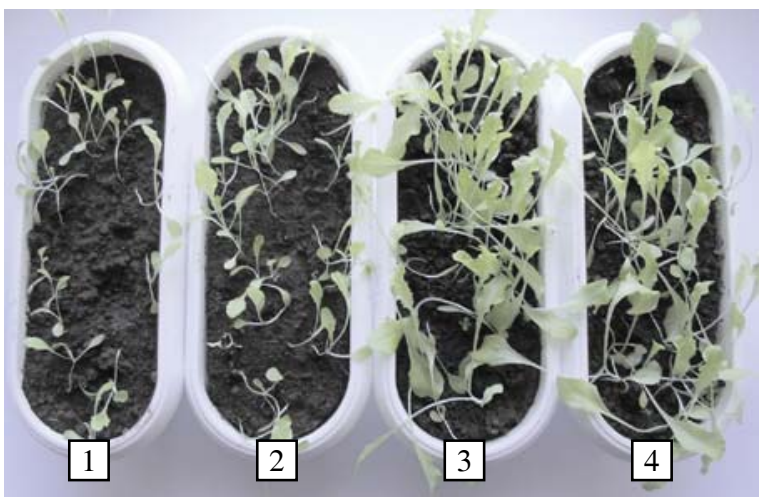

Fig 1. Lettuce samples were grown in substrates of different composition: 1,2 - soil; 3,4- soil and sewage sludge 3:1

One of the biggest differences was noticed between the lettuce grown in the unfertilized soil and the lettuce grown in the peat substrate. The lettuce grown in the peat substrate was taller and its leaves were several times bigger compared to those of the lettuce grown in the unfertilized soil (Fig 2).

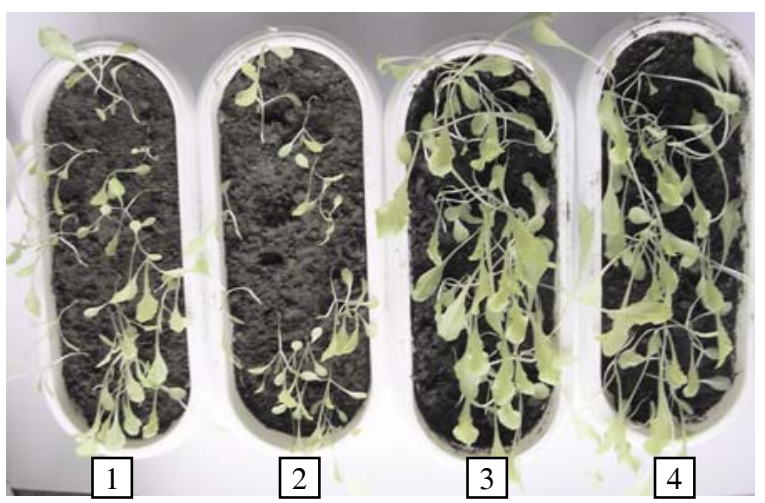

Fig 2. Lettuce samples were grown in substrates of different composition: 1,2 - soil; 3,4 - peat substrate

The biggest difference was also noticed between the lettuce grown in the unfertilized soil and the lettuce grown in the soil fertilized with sludge and potassium sulphate. Lettuce samples grown in the soil with sewage sludge 3:1 and $\mathrm{K}_{2} \mathrm{SO}_{4}$ were the tallest and had the biggest leaves compared to the other lettuce samples (Fig 3).

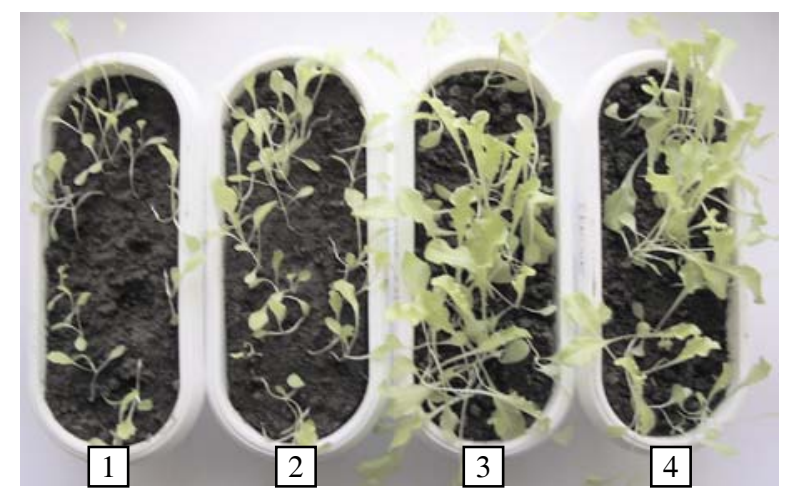

Fig 3. Lettuce samples were grown in substrates of different composition: 1,2 - soil; 3, 4- soil and sewage sludge $3: 1$ and $1,0 \mathrm{~g} \mathrm{~K}_{2} \mathrm{SO}_{4}$
Lettuce grew better in sewage sludge in comparison with those grown in soil, but worse than the lettuce grown in the soil with sludge or sludge and potassium sulphate (Fig 4).

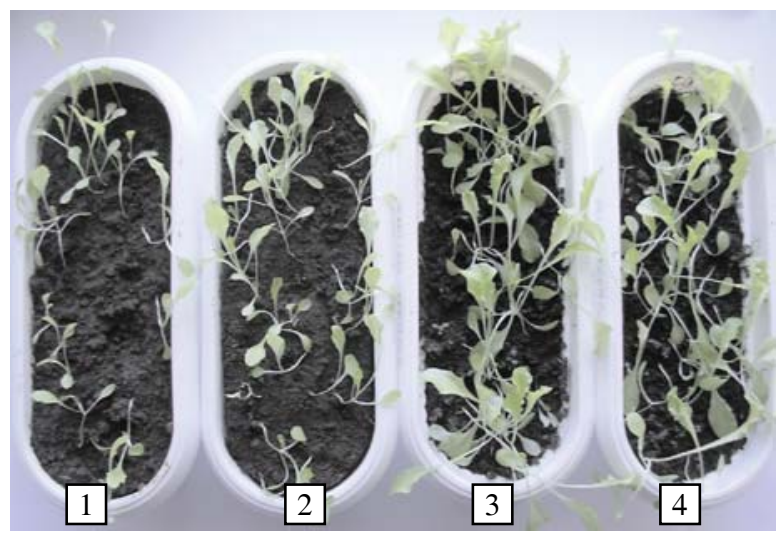

Fig 4. Lettuce samples were grown in substrates of different composition: 1,2 - soil; 3, 4- sewage sludge

On the $10^{\text {th }}$ day after a visual evaluation it was already seen that the lettuce grown in the substrate with sewage sludge are taller compared to those grown in the unfertilized soil.

The study was finished after 28 days. On the last day the terraneous part of plants was weighed, the common biomass of the samples and the average mass in a sample was calculated; the height of lettuce was measured. The data obtained is available in Table 2 and Figs 5-7.

Table 2. Lettuce height, average mass of each plant and common biomass in substrates of different composition

\begin{tabular}{|c|c|c|c|}
\hline \multirow[b]{2}{*}{$\begin{array}{l}\text { Substrates of different } \\
\text { compositions }\end{array}$} & \multicolumn{2}{|c|}{ Lettuce mass, $\mathrm{g}$} & \multirow[b]{2}{*}{$\begin{array}{c}\text { Average } \\
\text { lettuce } \\
\text { height, } \mathrm{cm}\end{array}$} \\
\hline & Common & $\begin{array}{c}\text { Average } \\
\text { of one } \\
\text { plant }\end{array}$ & \\
\hline Peat substrate & 29,2 & 0,621 & $17,5 \pm 0,59$ \\
\hline Soil & 8,4 & 0,191 & $6,5 \pm 0,53$ \\
\hline $\begin{array}{l}\text { Soil and sewage sludge } \\
3: 1\end{array}$ & 35 & 0,745 & $19 \pm 0,66$ \\
\hline $\begin{array}{l}\text { Soil and sewage sludge } \\
3: 1 \text { and } 1,0 \mathrm{~g} \mathrm{~K}_{2} \mathrm{SO}_{4}\end{array}$ & 43 & 0,935 & $21,5 \pm 0,67$ \\
\hline $\begin{array}{l}\text { Soil and sewage sludge } \\
1: 1\end{array}$ & 28,8 & 0,600 & $18,1 \pm 0,63$ \\
\hline $\begin{array}{l}\text { Soil and sewage sludge } \\
1: 1 \text { and } 1,0 \mathrm{~g} \mathrm{~K}_{2} \mathrm{SO}_{4}\end{array}$ & 38,6 & 0,919 & $19,3 \pm 0,66$ \\
\hline Sewage sludge & 25,0 & 0,543 & $18,5 \pm 0,64$ \\
\hline
\end{tabular}

The lowest biomass of lettuce was attained in the test sample of soil. Sludge added to this soil increased the biomass 3,4-4,2 times. Pure sludge is less suitable for growing lettuce than the substrates of soil and sludge, however, the biomass was 3 times higher compared to the check sample (Fig 5). The results obtained prove that 
sewage sludge from the acid casein production can be applied in fertilization to improve the quality of the soil.

An especially significant increase in the biomass was noticed in the samples where soil was fertilized not only with sludge but also with potassium sulphate. The differences between the samples of soil-sludge and those of soil-sludge-potassium sulphate demonstrated that the biomass was by $8-10 \%$ higher due to potassium sulphate.

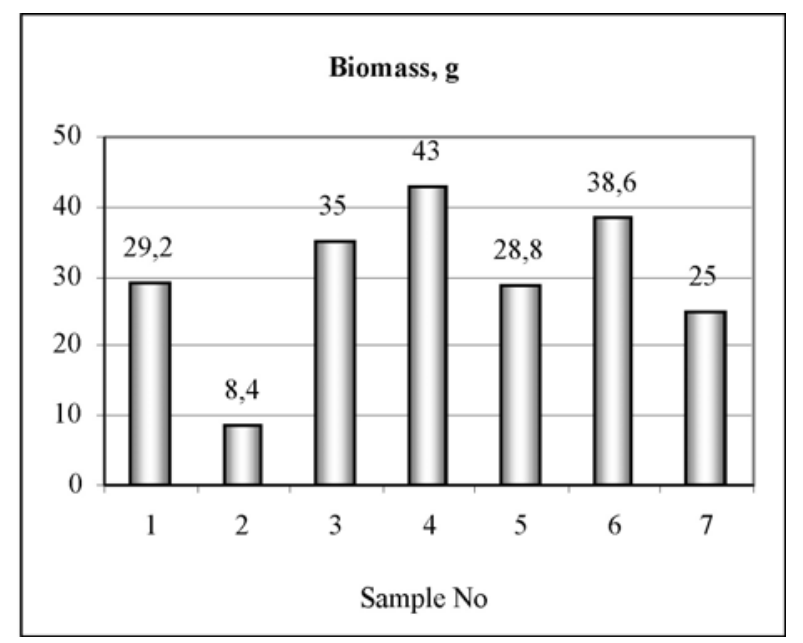

Fig 5. Lettuce biomass in substrates of different composition: 1 - peat substrate; 2 - soil; 3 - soil and sewage sludge $3: 1 ; 4-$ soil and sewage sludge $3: 1$ and $1,0 \mathrm{~g}$ $\mathrm{K}_{2} \mathrm{SO}_{4} ; 5$ - soil and sewage sludge $1: 1 ; 6$ - soil and sewage sludge $1: 1$ and $1,0 \mathrm{~g} \mathrm{~K}_{2} \mathrm{SO}_{4} ; 7$ - sewage sludge

Although the common biomass depends on the amount of germinated seeds as well, the differences of the biomass did not change after the calculation of the average mass of lettuce (Fig 6).

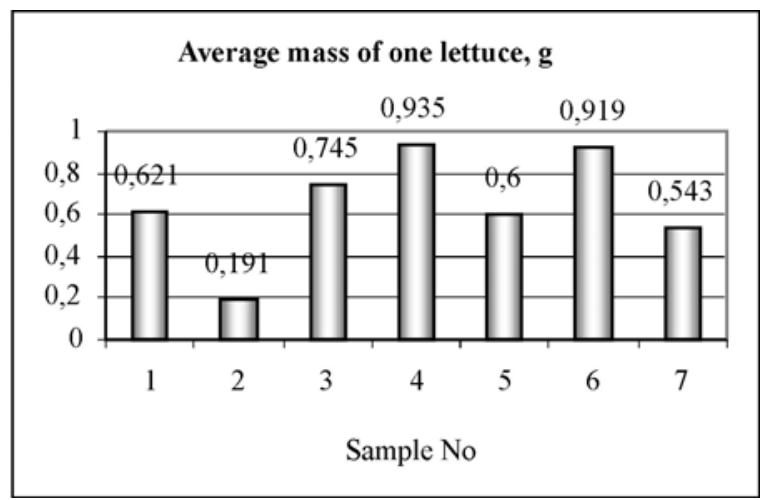

Fig 6. Lettuce average mass of plant in substrates of different composition: 1 - peat substrate; 2 - soil; 3 - soil and sewage sludge $3: 1 ; 4-$ soil and sewage sludge $3: 1$ and $1,0 \mathrm{~g} \mathrm{~K}_{2} \mathrm{SO}_{4} ; 5$ - soil and sewage sludge $1: 1 ; 6$ - soil and sewage sludge $1: 1$ and $1,0 \mathrm{~g} \mathrm{~K}_{2} \mathrm{SO}_{4} ; 7$ - sewage sludge

The calculations of the average height of lettuce showed that the tallest lettuces were grown in the sample with soil and sewage sludge $3: 1$ and $\mathrm{K}_{2} \mathrm{SO}_{4}$. The average lettuce height in the check sample with soil was 2-3 times lower than in the other samples (Fig 7).

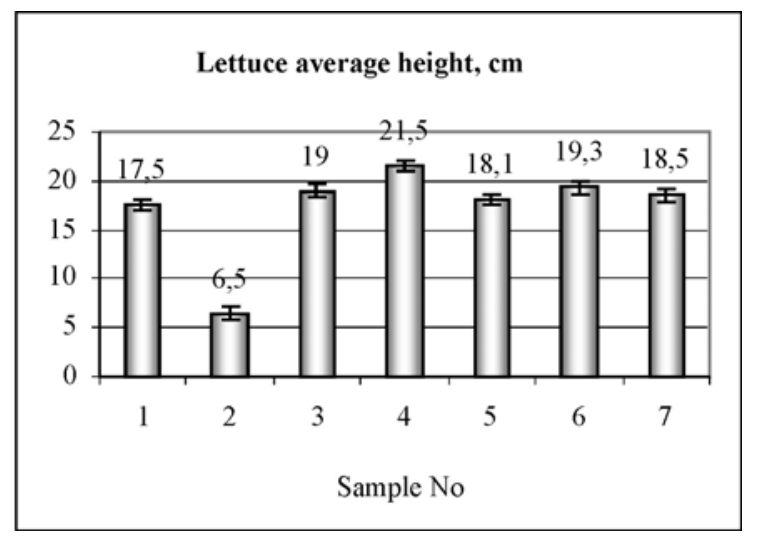

Fig 7. Lettuce average height in substrates of different compositions: 1 - peat substrate; 2 - soil; 3 - soil and sewage sludge $3: 1 ; 4$ - soil and sewage sludge $3: 1$ and 1,0 $\mathrm{g} \mathrm{K}_{2} \mathrm{SO}_{4} ; 5$ - soil and sewage sludge $1: 1 ; 6$ - soil and sewage sludge $1: 1$ and $1,0 \mathrm{~g} \mathrm{~K}_{2} \mathrm{SO}_{4} ; 7$ - sewage sludge

Analysis of garden cress. Vegetative samples were prepared and the germination of seeds was defined after 7 days. The Room temperature ranged from 22 to $24{ }^{\circ} \mathrm{C}$. The highest germination level of $94 \%$ was found in the peat substrate, while the lowest germination level was found in sewage sludge - of $82 \%$. The differences between the germination of garden cress grown in soil and in soil fertilized with sewage sludge showed that the most suitable ratio of sludge and soil was 3:1. Garden cress grown in this sample also produced the highest biomass. The data of germination of garden cress is presented in Table 3.

3 lentelè. Data of germination of garden cress

\begin{tabular}{l|c}
\hline \multicolumn{1}{c|}{ Substrates of different composition } & Seed germination, $\%$ \\
\hline Peat substrate & 94 \\
\hline Soil & 84 \\
\hline Soil and sewage sludge $3: 1$ & 91 \\
\hline Soil and sewage sludge $1: 1$ & 88 \\
\hline Sewage sludge & 82 \\
\hline
\end{tabular}

Comparison between the germination of garden cress and lettuce is presented in Fig 8. The germination level of lettuce and garden cress was the same only when plants were grown in peat substrate of $94 \%$. The germination levels differed when plants were grown in soil with sewage sludge: a higher germination level of lettuce was obtained when lettuce was grown in sewage sludge, while garden cress germinated better in soil. The level of germination was higher in soil fertilized with sewage sludge in comparison with the results of germination obtained in soil and sewage sludge. However, a better germination is achieved when garden cress and lettuce are grown in soil with sewage sludge the ratio of which is $3: 1$ and $1: 1$, respectively. 


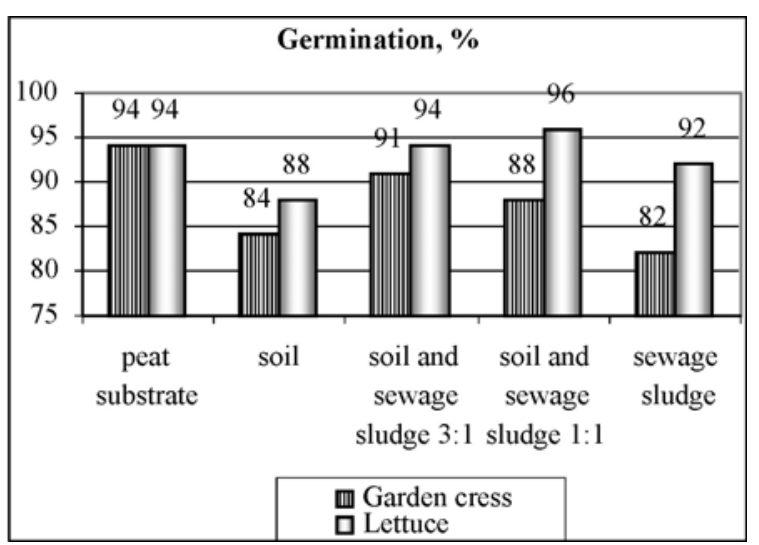

Fig 8. Germination of garden cress and lettuce in substrates of different composition

It was noticed that the highest germination level of garden cress was achieved when soil was fertilized with sludge 3:1, however, increasing concentration of sludge reduced the amount of germinated garden cress. The lowest germination level was noticed in sewage sludge. Garden cress is sensitive to changes of concentrations of biogenic and toxic matter as well as acidity. It may be assumed that these factors reduced the germination of garden cress.

\section{Conclusions}

1. Sewage sludge from the acid casein production added to soil increases the germination of lettuce and garden cress by $8 \%$ and $7 \%$, respectively.

2. The most suitable ratio of soil and sludge is $1: 1$ for the germination of lettuce, and 3:1 for the germination of garden cress.

3. The highest parameters of biomass were achieved in growing lettuce in the substrate of soil, sewage sludge and potassium sulphate: the height of lettuce increased 3,3 times, and the common biomass was 5,1 times larger than in the case of lettuce grown in an unfertilized soil.

4. Potassium sulphate improves the mineral composition of the substrate, made of sewage sludge from the acid casein production and soil, and increases the biomass of plants.

\section{References}

1. BALTRĖNAS, P.; RAISTENSKIS, E.; ZIGMONTIENĖ, A. Organinių atliekų biodestrukcijos proseso metu išsiskiriančių bioduju eksperimentiniai tyrimai. Journal of Environmental Engineering and Landscape Management, 2004, Vol XII, Suppl 1, p. 3-9.

2. GRAŽULEVIČIENĖ, R. Aplinkos epidemiologija ir rizikos sveikatai quvertinimas. Kaunas, 2005. 291 p.

3. DILBA, A.; MATUZEVIČIUS, A.; SARGŪNAS, G. Veiksniai, turintys ịtakos nuotekų, susidarančiu gaminant etanoli, valymo anaerobiniuose reaktoriuose efektyvumui. Journal of Environmental Engineering and Landscape Management (Aplinkos inžinerija), Vol IX, No 4. Vilnius: Technika, 2001, p. 211-216.

4. MALSEVA, O.; VOSTRIKOV, S.; YEFIMOV, Yu. Proposal for solving ecological problems in alcohol production. Journal of Environmental Engineering and Landscape Management, 2003, Vol XI, Suppl 1, p. 27-31.

5. STRUSEVIČIUS, Z. Nuoteku, atlieku ir méšlo tvarkymas žemés ūkyje. Vilainiai, 1996. 135 p.

6. STEPONAVIČIUS, A. Tręšimo pieno perdirbimo įmonių nuoteku dumblu tyrimai. LŽŨU mokslo darbai, 23(43)24(44). Vilainiai, 2003, p. 55-59.

7. Grunto valymo technologijos. Skystos atliekos ir nuotekos žemés ūkyje. Vilnius, $2005.99 \mathrm{p}$.

8. RODINOVA, N. Aplication of membrane methods for treating waste water in daires. Journal of Environmental Engineering and Landscape Management (Aplinkos inžinerija), Vol X, No 2. Vilnius: Technika, 2002, p. 84-88.

9. BUTĖNIENĖ, Ž.; TOTORAITIS, E. A. Nuotekų dumblo utilizacija. Iš 7-osios Lietuvos jaunuju mokslininku konferencijos „Lietuva be mokslo - Lietuva be ateities“, ivykusios Vilniuje $2004 \mathrm{~m}$. kovo $25 \mathrm{~d}$., pranešimu medžiaga. Aplinkos apsaugos inžinerija. Vilnius: Technika, 2004, p. 47-54.

10. EITMINAVIČIŪTĖ, I.; BAGDAVAVIČIENĖ, Z.; KISIELIS, V.; JANELIAUSKIENĖ, D. Vilniaus miesto nuotèku valyklos dumblo ekologinis ivertinimas. Vilnius, 2001.99 p.

11. Nuotèku dumblo naudojimo tręšimui bei rekultivavimui reikalavimai. LAND 20-2005. Žin., 2005, Nr. 142-5135.

12. STEPONAVIČIUS, A., STRUSEVIČIUS, Z. Kalkių panaudojimo maisto pramonès įmonių nuotekoms apvalyti priemonių tyrimai. LŽŨU mokslo darbai, 20(42). Vilainiai, 2002, p. 12-16.

13. ONAITIS, A. Tręšimas: monografija. Vilnius, 1989. 177 p.

\section{RŪGŠTINIO KAZEINO GAMYBOS NUOTEKŲ DUMBLO NAUDOJIMAS DIRVOŽEMIUI TRĘŠTI}

\section{E. Zuokaitè, D. Ščupakas}

\section{Santrauka}

Organinėms biodegraduojamoms atliekoms tenka nemaža ūkinės ir gyvybinès veiklos atliekų dalis. Jų deponavimas komunalinių atliekų sąvartynuose yra susijęs su aplinkos ir dirvožemio tarša. Todèl Europos Sajungos ir kitose pasaulio šalyse ieškoma tinkamų alternatyvų biodegraduojamoms atliekoms tvarkyti. Išnagrinètos rūgštinio kazeino gamybos nuotekų valymo įrenginiuose susidarančio dumblo savybės, apžvelgta dumblo tvarkymo ir naudojimo patirtis.

Atlikus eksperimenta, nustatyta, kad rūgštinio kazeino gamybos nuotekų dumblas tinka dirvožemiui trę̌sti auginant salotas (Lactuca sativa L.) ir sejjamąsias pipirnes (Lepidium sativum L.). Patręšus dirvožemi šiuo dumblu, padidèjo salotų ir pipirnių daigumas, išauginta didesné bandomujų maistiniu augalų biomasé. Nustatytas tinkamiausias dirvožemio ir dumblo mišinio santykis (salotoms - 1:1, pipirnèms - 3:1). I dirvožemio ir dumblo mišini pridejjus kalio sulfato, pagerejo maistinių augalų derlingumo parametrų vertès.

Reikšminiai žodžiai: rūgštinis kazeinas, nuotekų dumblas, tręšimas. 


\section{ПРИМЕНЕНИЕ ИЛА СТОЧНЫХ ВОД ПОСЛЕ ПРОИЗВОДСТВА КИСЛОТНОГО КАЗЕИНА ДЛЯ УДОБРЕНИЯ ПОЧВЫ}

\section{Э. Зуокайте, Д. Шчюпакас \\ Резюме}

Биологически деградирующие органические отходы составляют немалую часть отходов от хозяйственной деятельности и жизнедеятельности. Хранение их в коммунальных мусорных свалках вызывает загрязнение среды и почвы. Потому в Евросоюзе и других странах мира ведутся поиски альтернативных вариантов для очищения биологически деградирующих отходов. В статье рассмотрены свойства ила, образующегося в очищающих установках сточных вод, а также опыт по очистке и применению ила.

В результате зксперимента установлено, что ил сточных вод после производства кислотного казеина можно применять для удобрения почвы при выращивании салата (Lactuca sativa L.) и кресс-салата (Lepidium sativum L.). После удобрения почвы этим илом увеличилась растительность салата и кресс-салата, выращено больше биомассы пробных пищевых растений. Установлено приемлемое соотношение почвы и ила (для салата - 1:1, кресс-салата - 3:1). После прибавления в смесь почвы и ила сульфата калия улучшились значения параметров урожайности пищевых растений.

Ключевые слова: кислотный казеин, ил сточных вод, удобрение.

Eglè ZUOKAITE், PhD student (since 2005), Dept of Environmental Protection, Vilnius Gediminas Technical University (VGTU).

Research interests: utilization of sewage sludge from acid casein production for soil fertilization.

Davidas ŠČUPAKAS. Dr, Assoc Prof, Dept of Environmental Protection, Vilnius Gediminas Technical University (VGTU).

Doctor of Science (public health), Vilnius University, 1962, Employment: Assoc Prof, Dept of Environmental Protection, VGTU, since 1999; State Environmental Health Centre, since 1990; Hygiene Research Institute, 1964-1970. Publications: author of 35 research papers. Research interests: environmental health. 